\title{
Finding a Pulse: Melt Formation and Timing in the Garhwal Himalaya
}

\author{
Charlie J. OLDMAN ${ }^{1}$, Clare J. WARREN ${ }^{1}$,
} Christopher J. SPENCER ${ }^{2}$, TOM W. ARGLES ${ }^{1}$, NigEL B.W. HARRIS ${ }^{1}$, AND SAM J. HAMMOND ${ }^{1}$

${ }^{1}$ School of Environment, Earth and Ecosystem Sciences, The Open University, Milton Keynes MK7 6AA, UK

${ }^{2}$ Department of Geological Sciences and Geological Engineering, Queen's University, Kingston, Ontario KL7 3N6, Canada

The most significant consequence of prograde metamorphism for orogenic evolution is the melting of highgrade metamorphic rocks, resulting in a dramatic decrease in local mechanical strength, the activation of shear zones and consequent exhumation. The timescales of anatexis, amalgamation, migration, and emplacement therefore have implications for overall orogenic tectonic development. Across the Himalayan orogen, granite bodies and migmatites, formed by the melting of regional amphibolite-grade pelitic rocks, are found in the Greater Himalayan Sequence (GHS). Many of these granites formed during the Miocene when decompression during exhumation triggered melting; exact timings and reaction pathways vary laterally across the orogen. Recent studies suggest such S-type granite plutons form via the amalgamation of a series of pulsed melting events under low melt-fraction conditions followed by protracted periods of crystallisation. Geochemical signatures of these processes in granites, migmatites, and melt-extracted restite help to delineate more precisely the relevant processes and timescales leading to magma genesis. We sampled leucogranites, migmatites, and their host metasediments along the Rishi Ganga (Badrinath) and Alaknanda valleys in the Garhwal region of the Indian Himalaya. We present a preliminary zircon rim $\mathrm{U}-\mathrm{Pb}, \mathrm{O}, \mathrm{Hf}$ and trace-element dataset that helps to constrain the source, melt reactions, and timescales of melting episodes which form the migmatites and leucogranites of the upper GHS. Preliminary findings suggest that the leucogranites crystallised from $22 \mathrm{Ma}$ to $\sim 13$ $\mathrm{Ma}$, with punctuated zircon crystallisation occurring throughout this timespan. Migmatite zircon rim ages are generally older, ranging from $34 \mathrm{Ma}$ to $\sim 15 \mathrm{Ma}$. Integration of the $\mathrm{O}$ and Hf-isotopic, and trace element data, combined with petrographic observations allow mineral age data to be linked to changes in geological processes. 